\title{
Copper Supplementation in Watering Solution Reaches the Xylem But Does Not Protect Tobacco Plants Against Xylella fastidiosa Infection
}

\author{
Qing Ge, ${ }^{1}$ Paul A. Cobine, ${ }^{2}$ and Leonardo De La Fuente ${ }^{1, \dagger}$ \\ ${ }^{1}$ Department of Entomology and Plant Pathology, Auburn University, Auburn, AL 36849 \\ ${ }^{2}$ Department of Biological Sciences, Auburn University, Auburn, AL 36849
}

\begin{abstract}
Xylella fastidiosa is a xylem-limited plant pathogenic bacterium that causes disease in many crops worldwide. Copper $(\mathrm{Cu})$ is an antimicrobial agent widely used on $X$. fastidiosa hosts to control other diseases. Although the effects of $\mathrm{Cu}$ for control of foliar pathogens are well known, it is less studied on xylem-colonizing pathogens. Previous results from our group showed that low concentrations of $\mathrm{CuSO}_{4}$ increased biofilm formation, whereas high concentrations inhibited biofilm formation and growth in vitro. In this study, we conducted in planta experiments to determine the influence of $\mathrm{Cu}$ in $X$. fastidiosa infection using tobacco as a model. $X$. fastidiosa-infected and noninfected plants were watered with tap water or with water supplemented with $4 \mathrm{mM}$ or $8 \mathrm{mM}$ of $\mathrm{CuSO}_{4}$. Symptom progression was assessed, and sap and leaf ionome analysis was performed by inductively coupled plasma with optical emission spectroscopy. Cu uptake

was confirmed by increased concentrations of $\mathrm{Cu}$ in the sap of plants treated with $\mathrm{CuSO}_{4}$-amended water. Leaf scorch symptoms in $\mathrm{Cu}$-supplemented plants showed a trend toward more severe at later time points. Quantification of total and viable $X$. fastidiosa in planta indicated that $\mathrm{CuSO}_{4}$ amended treatments did not inhibit but slightly increased the growth of $X$. fastidiosa. $\mathrm{Cu}$ in sap was in the range of concentrations that promote $X$. fastidiosa biofilm formation according to our previous in vitro study. Based on these results, we proposed that the plant $\mathrm{Cu}$ homeostasis machinery controls the level of $\mathrm{Cu}$ in the xylem, preventing it from becoming elevated to a level that would lead to bacterial inhibition.

Keywords: copper homeostasis, $\mathrm{Cu}$, drench, ionome, systemic, vascular pathogen
\end{abstract}

Xylella fastidiosa is a Gram-negative plant pathogenic bacterium that causes diseases in many economically important crops worldwide, such as grape, citrus, plum, coffee, blueberry, peach (Hong et al. 2015; Hopkins and Purcell 2002; Purcell and Hopkins 1996), and olive (Saponari et al. 2019). In the United States, X. fastidiosa-caused diseases with the most economic impact are Pierce's disease of grapevine and bacterial leaf scorch of blueberry (Oliver et al. 2015). X. fastidiosa is transmitted by xylem-feeding insects such as sharpshooters and leafhoppers (Janse and Obradovic 2010). Once the bacteria get inside the plant xylem, they colonize xylem vessels and form biofilm that blocks water and nutrient transport (Chatterjee et al. 2008; Newman et al. 2003). This blockage is thought to lead to the development of leaf scorch, which is the typical symptom of $X$. fastidiosa (Chatterjee et al. 2008). Because of the internal niche (xylem) that $X$. fastidiosa colonizes, regular application methods of antibacterial treatments such as foliar sprays cannot easily reach the pathogen. Therefore, controlling $X$. fastidiosa-caused disease is a significant challenge.

Copper $(\mathrm{Cu})$-based microbicides have been widely used in agriculture since the 1880 s to control fungal diseases, such as downy mildew in grape (Brun et al. 1998; Rusjan 2012), as well as bacterial diseases (Lamichhane et al. 2018). Cu is toxic to bacteria because of the disruption of essential iron sulfur cluster proteins and it produces reactive oxygen species that lead to lipid and protein damage that can trigger plant defense response (Macomber and Imlay 2009; Sharma and Dietz 2009; Solioz et al. 2010). Although diseases can be managed by $\mathrm{Cu}$

${ }^{\dagger}$ Corresponding author: L. De La Fuente; 1zd0005@auburn.edu

Funding: This work was funded by the National Institute of Food and Agriculture (grant 2015-67014-23085), California Department of Food and Agriculture (grant PD-GWSS), China Scholarship Council (to Q. Ge), and Alabama Agricultural Experiment Station (HATCH funds to L. De La Fuente and P. Cobine).

The author(s) declare no conflict of interest.

Accepted for publication 7 October 2019.

(C) 2020 The American Phytopathological Society applications, the lack of curative or systemic activity leads to $\mathrm{Cu}$ spray applications year after year (Bender and Cooksey 1987; Graham et al. 2010). Therefore, thousands of tons of $\mathrm{Cu}$ are used annually in agriculture all over the globe, leading to $\mathrm{Cu}$ accumulation in soil. Considering arable land in Europe, the highest $\mathrm{Cu}$ concentration is found in vineyards (Ballabio et al. 2018), where it often exceeds the maximum residue level allowed (200 mg/kg of Cu) (Brunetto et al. 2016; Komárek et al. 2010). Exceptionally high concentrations of $\mathrm{Cu}$ in vineyard soils have been observed in France $(>1,000 \mathrm{mg} / \mathrm{kg}$ ) (Flores-Vélez et al. 1996) and Brazil (>3,000 mg/kg) (Mirlean et al. 2007). Because $X$. fas tidiosa lives inside grapes, the bacterium could be exposed to high $\mathrm{Cu}$ concentrations taken from the soil by the host plant roots and distributed via the xylem. Moreover, bacteria could theoretically acquire $\mathrm{Cu}$ resistance from this high $\mathrm{Cu}$-containing environment, such as $\mathrm{Cu}$ resistance acquisition described for citrus-associated xanthomonads (Behlau et al. 2013).

Research from Italy reported that a zinc ( $\mathrm{Zn})$ - and $\mathrm{Cu}$-containing citric acid biocomplex fertilizer (Dentamet) could influence $X$. fastidiosainfected olive trees by causing changes in polyphenolic and sugar content patterns, which may help plant defense against this pathogen infection (Girelli et al. 2017). The authors concluded that the $\mathrm{Cu}-\mathrm{Zn} \mathrm{ac}-$ cumulation using this complex reduced the progression of symptoms caused by X. fastidiosa in olive trees (Girelli et al. 2017; Scortichini et al. 2019). Previous results from our group showed that $\mathrm{Cu}$ influences $X$. fastidiosa growth in vitro. The addition of low $\mathrm{Cu}$ concentrations ( 5 to $200 \mu \mathrm{M}$ of $\mathrm{CuSO}_{4}$ ) to growth media increased biofilm formation in vitro, whereas high $\mathrm{Cu}$ concentrations $\left(>200 \mu \mathrm{M}\right.$ of $\left.\mathrm{CuSO}_{4}\right)$ reduced cell growth and therefore prevented biofilm formation. In addition, $\mathrm{Cu}$ in growth media influenced other virulence traits such as cell-cell adhesion (Cobine et al. 2013). However, the effect of $\mathrm{Cu}$ treatments on the growth of $X$. fastidiosa in planta is still unclear. In this study, we aimed to understand whether $\mathrm{CuSO}_{4}$ uptake by plants is effective to inhibit $X$. fastidiosa colonization in xylem vessels and whether its accumulation has an effect on disease development.

\section{Materials and Methods}

Bacterial strains and culture conditions. $X$. fastidiosa strain WM1-1 (Oliver et al. 2014; Parker et al. 2012) was used in this research and was grown using Periwinkle Wilt (PW) agar plates (Davis 
et al. 1981) or Pierce's Disease 2 (PD2) broth (Davis et al. 1980) incubated at $28^{\circ} \mathrm{C}$. Cell suspensions of $X$. fastidiosa used for plant inoculation (see below) were prepared following a previously described protocol with some modifications (De La Fuente et al. 2013). Briefly, X. fastidiosa strain WM1-1 was streaked from $-80^{\circ} \mathrm{C}$ frozen glycerol (20\%) stocks on PW agar plates for 5 to 7 days and then restreaked onto new plates for an additional 5 to 7 days. Next, bacterial cultures from PW agar plates were scraped and suspended in phosphate-buffered saline (PBS). Finally, bacterial suspensions were diluted to an optical density $\left(\mathrm{OD}_{600}\right)$ of 0.8 and used for plant inoculation.

Greenhouse experiments. Tobacco plants (Nicotiana tabacum 'Petite Havana SR1', plant introduction number 552516) were used as a model to study $X$. fastidiosa virulence and its host interaction, as previously described (De La Fuente et al. 2013). Tobacco seeds were obtained from the U.S. Department of Agriculture Germplasm Resources Information Network. Seeds were germinated in Sunshine Mix \#8 (Sun Gro Horticulture Canada Ltd.). After approximately 3 weeks, seedlings were transplanted to 4.5 -inch round pots. All plants were grown in the greenhouse at 20 to $25^{\circ} \mathrm{C}$ with natural sunlight. Plants were fertilized when they showed symptoms of deficiency (yellowing of leaves). Osmocote (Outdoor \& Indoor Smart-Release Plant Food; The Scotts Company, Marysville, $\mathrm{OH}$ ), a slow-release fertilizer, was added three times during the growing period. After an additional approximately 3 weeks of growth, plants were inoculated following a previously described method (De La Fuente et al. 2013; Francis et al. 2008). Briefly, only the three healthy lower leaves were kept, and the upper leaves were trimmed and discarded. Two milliliters $\left(\mathrm{OD}_{600}=0.8\right)$ of the bacterial inoculum was prepared as described above. A 23-gauge needle was used to puncture small wounds in the base of the leaf petioles that were quickly covered with $20 \mu \mathrm{l}$ of inoculum that was absorbed by the plant. Twenty-four plants were inoculated with the WM1-1 strain and the other 24 plants were injected with PBS buffer only (noninoculated control). A second inoculation was performed 1 week after the first inoculation, following the same method. Two weeks after cutting, new shoots grew from the trimmed leaf positions; therefore, trimming was performed to keep only one shoot for later growth. $\mathrm{Cu}$ amended plant treatments were carried out by watering each pot with $200 \mathrm{ml}$ of $4 \mathrm{mM} \mathrm{CuSO}_{4}, 8 \mathrm{mM} \mathrm{CuSO}_{4}$, or tap water (control). These $\mathrm{Cu}$ treatments were added once per week. The rest of the time, all plants were watered with the same amount of tap water. Treatments with additional $\mathrm{Cu}$ started 1 day after the first pathogen inoculation. At approximately 80 days after the first inoculation, symptoms (leaf scorch) started to show.

The number of plants showing leaf scorch and the number of leaves showing leaf scorch symptoms per plant were recorded weekly and used as measurements of disease incidence and severity, respectively. Disease severity was used to calculate the area under the disease progress curve (AUDPC). The AUDPC was calculated based on the midpoint rule method (Campbell and Madden 1990) as follows:

$$
\text { AUDPC }=\sum\left[\left(y_{i}+y_{i+1}\right) / 2\right]\left(t_{i+1}-t_{i}\right)
$$

where $\mathrm{i}$ is the number of assessment times, $\mathrm{y}$ is the disease severity score for each plant at each assessment, and $t$ is the time at each assessment. At the end of symptom development (around 4 weeks after the first symptoms were observed), samples were collected for further analysis as described below. An independent experiment was performed to determine $\mathrm{Cu}$ phytotoxicity in tobacco plants. Eight plants for each treatment were watered with $200 \mathrm{ml}$ of $12 \mathrm{mM}$ $\mathrm{CuSO}_{4}, 16 \mathrm{mM} \mathrm{CuSO}_{4}$, or tap water (control) once per week. The rest of the time, all plants were watered with the same amount of tap water. Symptoms of phytotoxicity were recorded over time.

Ionome characterization. Five leaves above the inoculation point from each one of the five selected plants from each treatment were collected for ionome analysis, following a previously described protocol with some modifications (De La Fuente et al. 2013). Briefly, whole leaves were dried immediately after collection by incubation at $65^{\circ} \mathrm{C}$ for $1 \mathrm{~h}$. These leaves were then ground to a fine powder with a mortar and pestle. For each sample, $10 \mathrm{mg}$ of the powder was taken and digested in $200 \mu \mathrm{l}$ of mineral-free concentrated nitric acid (OPTIMA; Fisher Scientific) at $100^{\circ} \mathrm{C}$ for $1 \mathrm{~h}$. After digestion, samples were diluted with $800 \mu$ l of mineral-free water, followed by centrifugation at $13,000 \times g$ to remove the remaining particulates. Finally, samples were analyzed by inductively coupled plasma with optical emission spectroscopy (ICP-OES) (7100 DV; PerkinElmer, Waltham, MA) with simultaneous measurement of calcium $(\mathrm{Ca})$, iron $(\mathrm{Fe}), \mathrm{Cu}, \mathrm{Zn}$, manganese $(\mathrm{Mn})$, sulfur $(\mathrm{S})$, magnesium $(\mathrm{Mg})$, potassium $(\mathrm{K})$, sodium $(\mathrm{Na})$, and phosphorus $(\mathrm{P})$. Mineral element concentrations were determined by comparing emission intensities to standard curves created from certified standards (SPEXCertiprep, Metuchen, NJ). Standard curves were confirmed by reanalysis of standard solutions diluted in a matrix equivalent to the sample. Individual readings (average of two intensity measurements) and repeated analysis of individual samples showed $<5 \%$ variation (data not shown)

For sap ionome analysis, five plants from each treatment group were selected, and one sap sample was collected from each plant. Sap samples were collected using a Scholander pump model 600 pressure chamber (PMS Instrument Company, Corvallis, OR) as described previously (Oliver et al. 2014). Samples were frozen at $-20^{\circ} \mathrm{C}$ for storage for no more than 1 week. Samples were diluted with mineral-free water and analyzed by ICP-OES as described above for leaf samples.

Total and viable bacterial population quantification. Bacterial population quantification was performed by quantitative PCR (qPCR) for total bacteria following a previously described protocol (De La Fuente et al. 2013) and by PMAxx-qPCR for viable cells. According to the product description (https://us.vwr.com/store/product/ 8286393/pmatm-pmaxxtm-pma-litetm-and-related-products-biotium), PMAxx (Biotium, Hayward, CA) is a photoreactive, cell membraneimpermeable dye that could bind with dsDNA, which then is no longer amplified by PCR. Thus, only dsDNA from live cells that was not bound to PMAxx could be amplified by PCR. Five petioles (positions 1 to 5 above the inoculation point, from bottom to top) from five selected plants per treatment were collected from both inoculated and noninoculated plants. Petioles were cut into small pieces, and 100-mg samples were put into 2-ml tubes with $2.0-\mathrm{mm}$ beads (ZIRCONIA; Biospec Products, Bartlesville, OK) and ground for 2 to $3 \mathrm{~min}$ at high speed using a mini Beadbeater 96 (Biospec Products). Samples were resuspended with $1.5 \mathrm{ml}$ of PD2 broth. From each sample, $500 \mu \mathrm{l}$ was transferred to a new tube and stored at $-20^{\circ} \mathrm{C}$ for later DNA extraction and quantification of total bacterial population. A second $500-\mu 1$ sample was transferred to a new tube for PMAxx treatment and quantification of viable bacterial populations. To assess the accuracy of PMAxx treatment for plant tissue samples, dead bacteria cell controls were prepared by treating ground petiole samples in a $95^{\circ} \mathrm{C}$ water bath for 30 min. PMAxx treatment was added to samples in the dark, mixed, and incubated for $5 \mathrm{~min}$. Then samples were exposed for $10 \mathrm{~min}$ to a strong light (700W halogen portable work light; Husky Co., Atlanta, GA). Ice was used to prevent samples from overheating from the light treatment. Samples were saved at $-20^{\circ} \mathrm{C}$ for later analysis. DNA of total and viable bacteria samples was extracted using a modified cetyltrimethylammonium bromide protocol (Doyle and Doyle 1987), and $X$. fastidiosa populations were quantified using qPCR and a standard curve as previously described (De La Fuente et al. 2013).

Statistical analyses. For the analysis of sap concentration of $\mathrm{Cu}$, all pairwise multiple comparison procedures were carried out with the Tukey test using SigmaPlot 14.0 (SigmaPlot for Windows; Systat Software Inc., Chicago, IL) $(P<0.05)$. For the analysis of disease symptoms and AUDPC, Poisson analysis in R software (version 3.6.1 for Windows) was used. For bacterial population quantification, $\mathrm{Cu}$ leaf concentration, and leaf ionome characterization, oneway analysis of variance (or Kruskal-Wallis for non-normal data) was used and means were separated by the Fisher protected least significant difference $(P<0.05)$ using Statistix 8.0 software (Analytical 
Software, St. Paul, MN). For leaf $\mathrm{Cu}$ concentration, data outliers were removed by the ROUT outliers test $(\mathrm{Q}=5 \%)$ using Prism 8 software for Mac OS 8.2 (GraphPad Software, La Jolla, CA).

\section{Results}

Cu uptake by tobacco plants. ICP-OES was used to determine the $\mathrm{Cu}$ concentration in tobacco sap (Fig. 1) and leaves (Fig. 2). The $\mathrm{Cu}$ concentration of plant sap in the $\mathrm{CuSO}_{4}$-amended treatments (4 and $8 \mathrm{mM}$ of $\mathrm{CuSO}_{4}$ ) significantly increased compared with the control groups (water treatment) (Fig. 1). In the control groups watered with unamended tap water, the average $\mathrm{Cu}$ concentration in sap was $0.68 \pm 0.09 \mu \mathrm{M}$ in noninoculated plants and $1.00 \pm$ $0.12 \mu \mathrm{M}$ in $X$. fastidiosa-inoculated plants. In 4-mM $\mathrm{CuSO}_{4^{-}}$ amended treatments, the $\mathrm{Cu}$ concentration was $46.12 \pm 3.17$ and $39.81 \pm 4.39 \mu \mathrm{M}$ for noninoculated and inoculated plants, respectively. In 8-mM $\mathrm{CuSO}_{4}$-amended plants, the $\mathrm{Cu}$ concentration was $103.51 \pm 8.94$ and $101.53 \pm 7.15 \mu \mathrm{M}$ for noninoculated and inoculated plants, respectively. In independent experiments, sap $\mathrm{Cu}$ concentrations ranged from 0.3 to $1.0 \mu \mathrm{M}$ for the control groups, 10 to $50 \mu \mathrm{M}$ for the 4-mM $\mathrm{CuSO}_{4}$-amended treatments, and 50 to $100 \mu \mathrm{M}$ for $8-\mathrm{mM} \mathrm{CuSO}_{4}$-amended treatments.

The $\mathrm{Cu}$ concentration in plant leaves was also quantified (Fig. 2). In control groups, leaves contained $2.97 \pm 0.12$ and $5.53 \pm 0.41$ $\mathrm{mg} / \mathrm{kg}$ of $\mathrm{Cu}$ for noninoculated plants and inoculated plants, respectively. Leaf $\mathrm{Cu}$ concentrations in 4-mM CuSO${ }_{4}$-amended treatments were significantly increased compared with the control groups $(46.87 \pm$ 5.95 and $99.81 \pm 12.67 \mathrm{mg} / \mathrm{kg}$ for noninoculated and inoculated plants, respectively). In 8-mM CuSO${ }_{4}$-amended treatments, $\mathrm{Cu}$ concentrations were $60.50 \pm 5.54$ and $172.52 \pm 26.07 \mathrm{mg} / \mathrm{kg}$ for noninoculated plants and inoculated plants, respectively. Leaf $\mathrm{Cu}$ concentrations ranged from 2 to $6 \mathrm{mg} / \mathrm{kg}$ for the control groups, 50 to $100 \mathrm{mg} / \mathrm{kg}$ for the $4-\mathrm{mM} \mathrm{CuSO}_{4}$-amended treatments, and 60 to $180 \mathrm{mg} / \mathrm{kg}$ for the $8-\mathrm{mM} \mathrm{CuSO}_{4}$-amended treatments.

$\mathrm{Cu}$-amended treatments affect other elements in tobacco leaves. Other elements in leaves besides $\mathrm{Cu}(\mathrm{Ca}, \mathrm{Fe}, \mathrm{Zn}, \mathrm{Mn}, \mathrm{S}$, $\mathrm{Mg}, \mathrm{K}, \mathrm{Na}$, and $\mathrm{P}$ ) were also measured by ICP-OES. As expected, increasing $\mathrm{Cu}$ added to plants also changed other elements in leaves (Fig. 3). In noninoculated plants (Fig. 3A), Fe, S, K, and P were significantly decreased in $\mathrm{Cu}$-amended treatments (in 4-mM $\mathrm{CuSO}_{4}$ treatment). Among them, the $\mathrm{Fe}$ concentration decreased $>40 \%$ from the control, whereas P and S decreased approximately 60 and $40 \%$

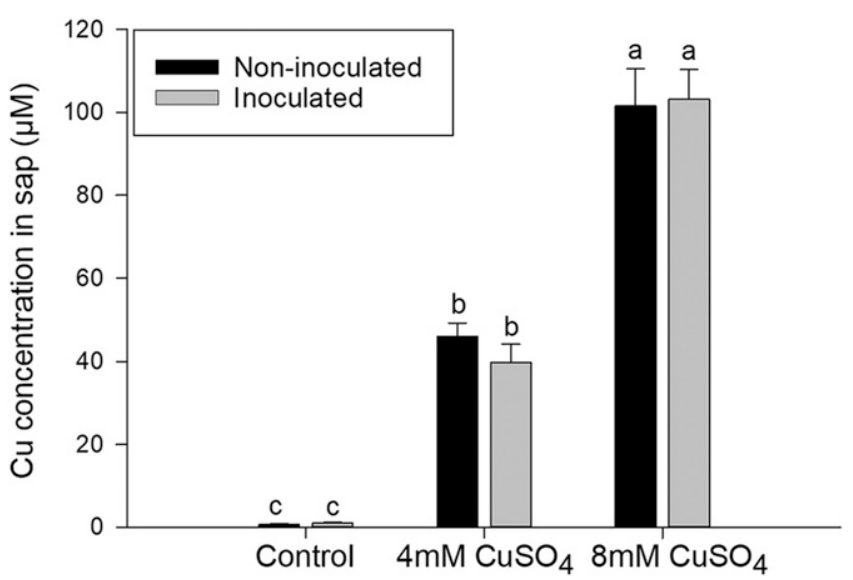

Fig. 1. Copper $(\mathrm{Cu})$ concentration in sap of tobacco plants. Sap samples were collected from tobacco plants (Nicotiana tabacum 'Petite Havana SR1') grown in the greenhouse. Half of the plants were inoculated with Xylella fastidiosa ("inoculated") and the other half were inoculated with phosphate-buffered saline ("noninoculated"). Plants were watered with $200 \mathrm{ml}$ of $4 \mathrm{mM} \mathrm{CuSO}_{4}, 8 \mathrm{mM} \mathrm{CuSO}_{4}$, or tap water (control) ( $n=5 /$ treatment). Mean values are shown in the graph, and error bars represent the standard error of the mean. Data used in the graph correspond to one representative experiment, and three independent experiments performed under the same conditions showed similar tendencies. Different letters above bars indicate significant differences $(P<0.05)$ among all treatments according to the Tukey test (all pairwise multiple comparison procedures) (SigmaPlot 14.0). from the control, respectively. $\mathrm{Zn}, \mathrm{Mn}$, and $\mathrm{Mg}$ concentrations increased significantly in $\mathrm{Cu}$-amended treatments in most cases. The concentration of $\mathrm{Mn}$ in leaves showed the highest increment (approximately $60 \%$ more than the control). In inoculated plants (Fig. 3B), most of the elements showed similar tendencies but different degrees of change compared with noninoculated plants. The exceptions were $\mathrm{Fe}$ and $\mathrm{S}$, which showed opposite tendencies. The comparison of leaf element concentration between noninoculated and inoculated plants in control groups (water only) showed the same tendencies (data not shown) as published previously (Oliver et al. 2014).

$\mathrm{CuSO}_{4}$-amended treatments had no significant effect on $X$. fastidiosa symptoms. Tobacco was shown in previous reports to be a suitable model to study $X$. fastidiosa virulence and pathogen-host interactions (De La Fuente et al. 2013; Francis et al. 2008; Oliver et al. 2014). Petite Havana SR1 tobacco plants showed symptoms of leaf scorch when inoculated with $X$. fastidiosa strain WM1-1. After 75 to 80 days postinoculation, symptoms of leaf scorch started to show in all $X$. fastidiosa-inoculated groups (Fig. 4A). After 3 weeks postsymptom appearance (wps), all inoculated plants had similar disease progress curves. Starting at 4 wps, $\mathrm{Cu}-$ amended treatments showed approximately $60 \%$ of leaves with scorch symptoms, whereas the control group (water only treatment) showed approximately $50 \%$ leaf scorch. These differences were increased at 5 wps when the $\mathrm{Cu}$-amended treatments showed leaf scorch from 65 to $75 \%$, whereas the control group showed the same symptoms at $55 \%$. The $\mathrm{Cu}$-amended treatments did not show any significant disease control effect, even showing a trend toward more severe disease than the control at later time points. After statistical analysis, only the 4- $\mathrm{mM} \mathrm{CuSO}_{4}$-amended treatment had significantly higher disease symptoms than the control group $(P=0.038)$ (data not shown) at the last time point considered in one of the repetitions of the experiment. However, these differences were nonsignificant in successive repetitions of the experiment. AUDPCs of the three experimental repetitions showed that symptoms of leaf scorch in the $\mathrm{Cu}-$ supplemented plants were generally more severe than the control

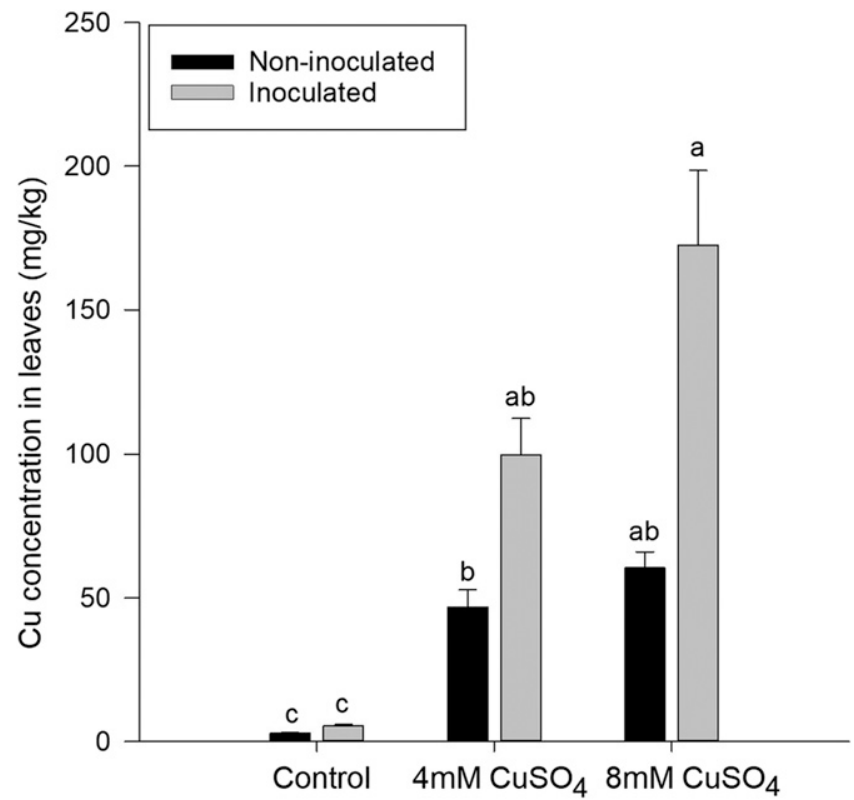

Fig. 2. Copper (Cu) concentration in leaves of tobacco plants. Leaf samples were collected from tobacco plants (Nicotiana tabacum 'Petite Havana SR1') grown in the greenhouse. Plants were inoculated with Xylella fastidiosa ("inoculated") or phosphate-buffered saline ("noninoculated"). Plants were watered with $200 \mathrm{ml}$ of either $4 \mathrm{mM} \mathrm{CuSO}_{4}, 8 \mathrm{mM} \mathrm{CuSO}_{4}$, or tap water (control). Five leaves per plant and five plants per treatment were collected ( $n=25 /$ treatment). Values in the graph represent means and error bars represent the standard error of the mean. Data used in the graph correspond to one representative experiment, and three independent experiments performed under the same conditions showed similar tendencies. Different letters on top of the bars indicate significant differences $(P<$ $0.05)$, according to the Kruskal-Wallis test (all pairwise multiple comparison test) (Statistix 8.0). 
but nonsignificantly different (Fig. 4B). These conclusions were the same in all three independent experiments.

In noninoculated plants watered with $8 \mathrm{mM}$ of $\mathrm{CuSO}_{4}$, minor symptoms of phytotoxicity were observed, expressed as a decrease of secondary shoot growth and a general reduction in plant growth. For this reason, we established additional treatments when plants were watered with higher concentrations (12 and $16 \mathrm{mM}$ ) of $\mathrm{CuSO}_{4}$, and we assessed the effect on plant growth. We observed that in the $12-\mathrm{mM} \mathrm{Cu}$-amended treatment, all plant growth was stunted with yellowing leaves. In the $16-\mathrm{mM} \mathrm{Cu}$-amended treatment, five of eight plants were dead after 7 weeks of treatment and the rest of the plants showed stunted growth.

$X$. fastidiosa populations in tobacco plants. qPCR and PMAxxqPCR were used to quantify the total and viable populations of $X$. fastidiosa, respectively. There were no significant differences in bacterial total populations among plants that received the control and $\mathrm{Cu}$-amended treatments (Fig. 5). After 4 wps (Fig. 5A), the average total bacteria population in plant leaf petioles was $5.75 \pm$ $0.05,5.59 \pm 0.03$, and $5.70 \pm 0.03 \log \mathrm{CFU} / \mathrm{mg}$ for the control group, 4- $\mathrm{mM} \mathrm{CuSO}_{4}$-amended treatment, and $8-\mathrm{mM} \mathrm{CuSO}_{4}$-amended treatment, respectively. At 8 wps (Fig. 5B), the average total bacterial population was $5.22 \pm 0.06,5.30 \pm 0.04$, and $5.41 \pm 0.04 \log$ $\mathrm{CFU} / \mathrm{mg}$ for the control group, 4-mM $\mathrm{CuSO}_{4}$-amended treatment, and 8- $\mathrm{mM} \mathrm{CuSO}_{4}$-amended treatment, respectively.

Viable bacterial populations were measured by PMAxx-qPCR. After 4 wps (Fig. 5A), the average viable bacteria population in plant leaf petioles was $3.08 \pm 0.06,3.25 \pm 0.12$, and $3.22 \pm 0.06 \log \mathrm{CFU} / \mathrm{mg}$ for the control group, 4-mM CuSO 4 -amended treatment group, and 8 - $\mathrm{mM} \mathrm{CuSO}_{4}$-amended treatment group, respectively. At 8 wps (Fig. 5B), the average viable bacterial population was $3.64 \pm 0.05$, $4.02 \pm 0.07$, and $4.05 \pm 0.07 \log \mathrm{CFU} / \mathrm{mg}$ for the control group, 4- $\mathrm{mM} \mathrm{CuSO}_{4}$-amended treatment group, and 8-mM CuSO${ }_{4}$-amended treatment group, respectively. At the later time point analyzed (8 wps), viable populations increased significantly with amendments of $\mathrm{CuSO}_{4}$ (Fig. 5B).

To assess the accuracy of the PMAxx treatment, a dead bacterial cell control was analyzed. After heat treatment of cells, PMAxxqPCR still reported viable bacterial populations of $2.18 \pm 0.09 \log$ $\mathrm{CFU} / \mathrm{mg}$, whereas the total population in the same sample assessed by qPCR was $4.46 \pm 0.02 \log \mathrm{CFU} / \mathrm{mg}$.

\section{Discussion}

In this study, we analyzed the effect of $\mathrm{Cu}$ accumulation in soil and subsequent uptake by roots of the plant host during $X$. fastidiosa infection. Our results show that $\mathrm{Cu}$ added as a soil drench to tobacco plants caused an increment in $\mathrm{Cu}$ concentrations in sap and leaves, but this did not inhibit disease nor the pathogen growth in planta. Interestingly, a higher $\mathrm{Cu}$ concentration in sap seems to enhance $X$. fastidiosa virulence, as noted by a nonsignificant trend of increase in disease symptom severity when $\mathrm{Cu}$ was added to the watering solution and by an increase in bacterial populations.

The $\mathrm{Cu}$ concentrations of tobacco sap and leaves were both increased (40- to 100-fold changes in sap and 15- to 30-fold in leaves) when plants were drenched with $\mathrm{CuSO}_{4}$ solution. This confirmed that $\mathrm{Cu}$ was successfully transported through the xylem system and represents the situation of plants growing in soils with high $\mathrm{Cu}$ content. Previous studies showed that many plants, such as grapevine and citrus, are exposed to high $\mathrm{Cu}$ in their environment as a result of agricultural practices. For vineyards, $\mathrm{Cu}$ in soil ranges from 77 up to 3,200 mg/kg (Mirlean et al. 2007; Ruyters et al. 2013). Grapevines that grow in a region where the $\mathrm{Cu}$ content in surface soil ( 0 to $10 \mathrm{~cm}$ ) is around $70 \mathrm{mg} / \mathrm{kg}$ were shown to accumulate approximately $800 \mathrm{mg} / \mathrm{kg}$ of $\mathrm{Cu}$ in leaves and approximately $10 \mathrm{mg} / \mathrm{kg}$ in vascular tissue (Angelova et al. 1999). Similar Cu concentrations in grapevines were found in a study by Lai et al. (2010). Under $\mathrm{Cu}$ amendments, the concentration in our study was approximately 50 to $100 \mu \mathrm{M}$ in sap (3.0 to $6.6 \mathrm{mg} / \mathrm{kg}$ of sap fluid) and approximately 50 to $180 \mathrm{mg} / \mathrm{kg}$ in leaves of dried plant tissue. Therefore, our experimental setting represents conditions at the low end of the range of $\mathrm{Cu}$ found in grapevines around the world, particularly in sap where
$X$. fastidiosa lives. In the studies mentioned above (Angelova et al. 1999; Lai et al. 2010), $\mathrm{Cu}$ was at much higher concentrations in leaves than in our experimental conditions, probably reflecting the fact that $\mathrm{Cu}$ was applied through leaf sprays in those studies; in our research, all $\mathrm{Cu}$ treatments were applied as soil drenches. Hippler et al. (2018) showed that in citrus trees, soil application and foliar application of $\mathrm{Cu}$ caused different $\mathrm{Cu}$ accumulation patterns. In soil applications, leaf $\mathrm{Cu}$ concentrations ranged between 10 and $30 \mathrm{mg} / \mathrm{kg}$, whereas this concentration increased up to $600 \mathrm{mg} / \mathrm{kg}$ after foliar applications (Hippler et al. 2018). The majority of $\mathrm{Cu}$ applied in the field is through foliar sprays, since it targets foliar pathogens. Although part of the $\mathrm{Cu}$ sprayed is taken up by plants through leaves, most of the washed-off $\mathrm{Cu}$ stays on the soil surface and will be accumulated year after year (Hippler et al. 2018; Mackie et al. 2012; Sun et al. 2018; Wightwick et al. 2008). Cu uptake and accumulation in plants could be crucial factors when considering plant disease management options related to $\mathrm{Cu}$-containing antimicrobial agents. For
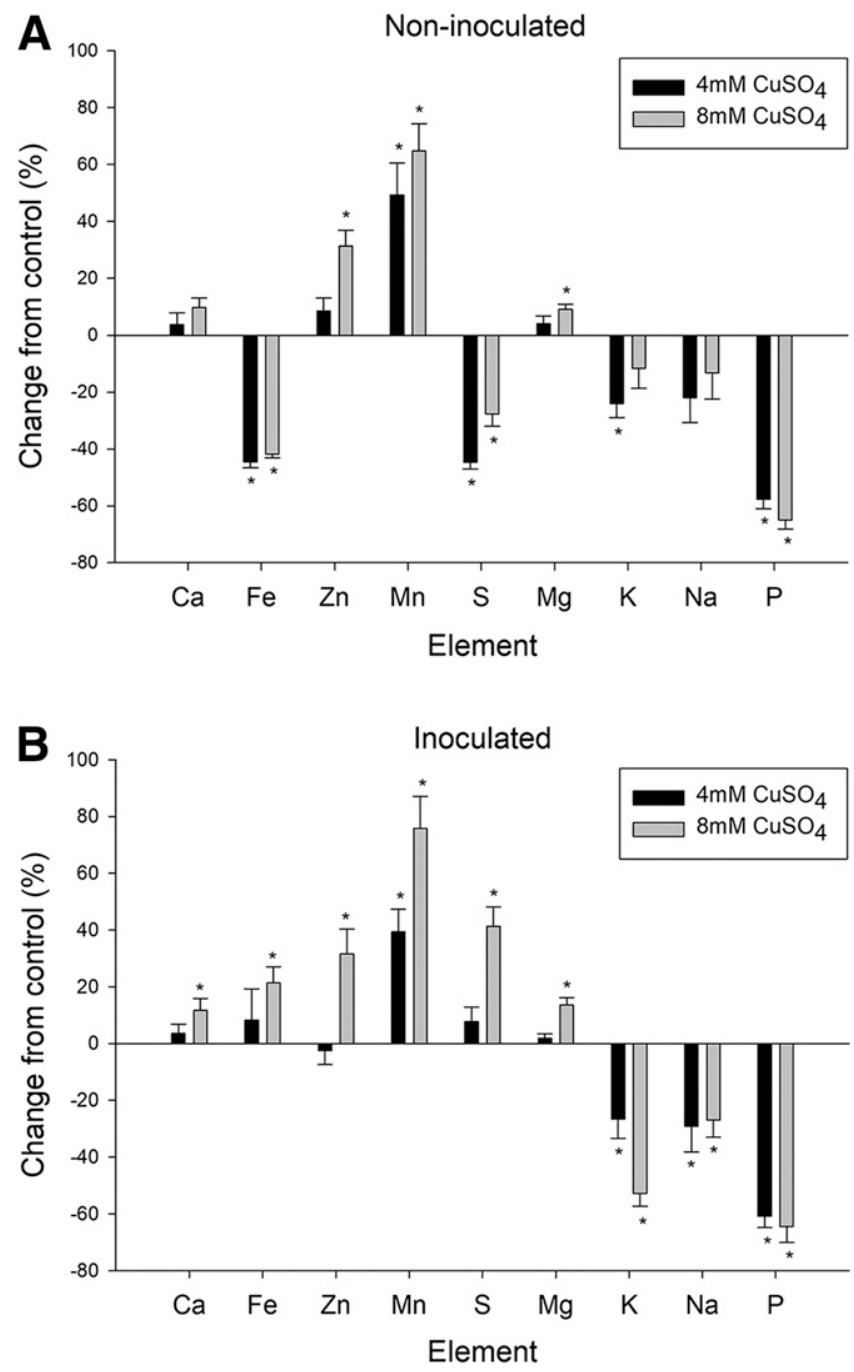

Fig. 3. lonome changes in tobacco plant leaves under copper (Cu)-amended treatments. lonome changes in plants inoculated with $\mathrm{A}$, phosphate-buffered saline ("noninoculated") or B, Xylella fastidiosa ("inoculated"). Elements calcium (Ca), iron $(\mathrm{Fe})$, zinc $(\mathrm{Zn})$, manganese $(\mathrm{Mn})$, sulfur $(\mathrm{S})$, magnesium $(\mathrm{Mg})$, potassium $(\mathrm{K})$, sodium $(\mathrm{Na})$, and phosphorus $(\mathrm{P})$ were measured from the same leaf samples used for $\mathrm{Cu}$ concentrations (Fig. 2). Plants were watered with either $200 \mathrm{ml}$ of $4 \mathrm{mM} \mathrm{CuSO}_{4}, 8 \mathrm{mM} \mathrm{CuSO}_{4}$, or tap water (control). Five leaves per plant and five plants per treatment were collected ( $n=25 /$ treatment). Values in the graphs represent means and error bars represent the standard error of the mean. Data used in the graph correspond to one representative experiment, and three independent experiments performed under the same conditions showed similar tendencies. Asterisks indicate a significant difference $(P<0.05)$ between treatments according to one-way analysis of variance or the Kruskal-Wallis test. 
$X$. fastidiosa management in the field, $\mathrm{Cu}$-contaminated soil needs to be taken into account owing to the fact that vineyards, citrus orchards, and other agriculture fields may have been through several decades of $\mathrm{Cu}$ applications (Wightwick et al. 2008). The $\mathrm{Cu}$ concentration in those plants could benefit pathogen growth, especially after regulated uptake into the plant vascular system via plant homeostatic machinery.

When we measured disease development, we did not observe any reduction in disease symptoms in the $\mathrm{Cu}$-amended treatments compared with controls; instead, we noticed a tendency to show more symptoms at higher $\mathrm{Cu}$ treatments. Bacterial populations were not reduced in $\mathrm{Cu}$-amended treatments compared with controls; instead, they had significantly more viable cells at 8 wps. In this study, the $\mathrm{Cu}$ concentration in tobacco sap was lower than $200 \mu \mathrm{M}$, which was the lowest concentration that significantly decreased $X$. fastidiosa biofilm formation and inhibited growth in our previous in vitro study (Cobine et al. 2013). In fact, the sap $\mathrm{Cu}$ concentration in $\mathrm{Cu}$ amended treatments ranged from 10 to $100 \mu \mathrm{M}$, which is within
A

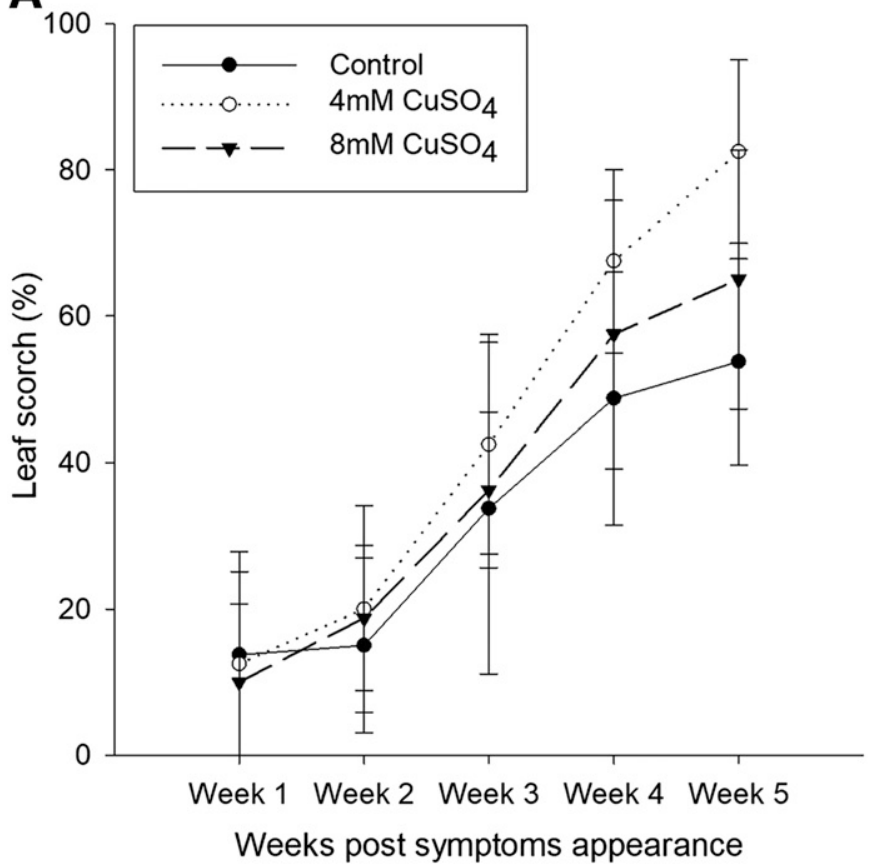

B

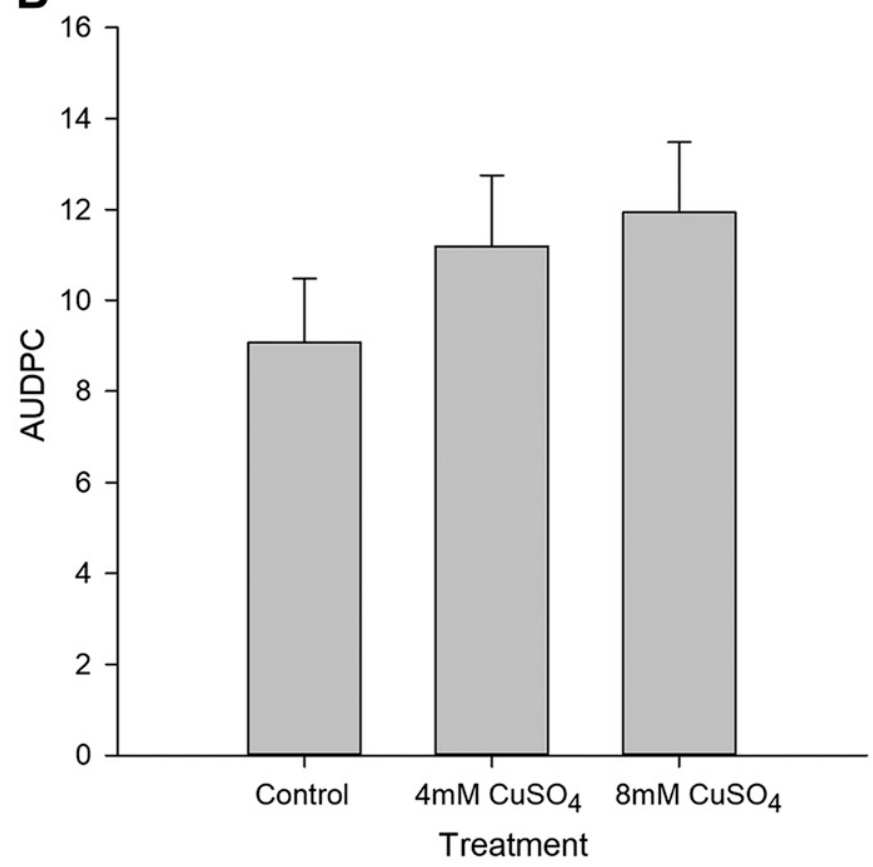

Fig. 4. Severity of Xylella fastidiosa-caused symptoms with $\mathrm{CuSO}_{4}$-amended treatments. A, Symptom development in tobacco plants. Disease severity is represented by the percentage of leaves showing scorch symptoms per plant. Eight plants were considered for each treatment. $\mathrm{B}$, Area under the disease progress curve (AUDPC). CuSO ${ }_{4}^{-}$ amended treatments showed a trend of increased disease symptoms compared with the control, but no significant differences were found between copper (Cu)-amended treatments and the control, according to the two-tailed Student $t$ test (Microsoft Excel 2016). Error bars in both A and B correspond to the standard error of the mean. Data used for $A$ correspond to one representative experiment, whereas data from the average of three experiments were used for B. Three independent experiments performed under the same conditions showed similar tendencies.

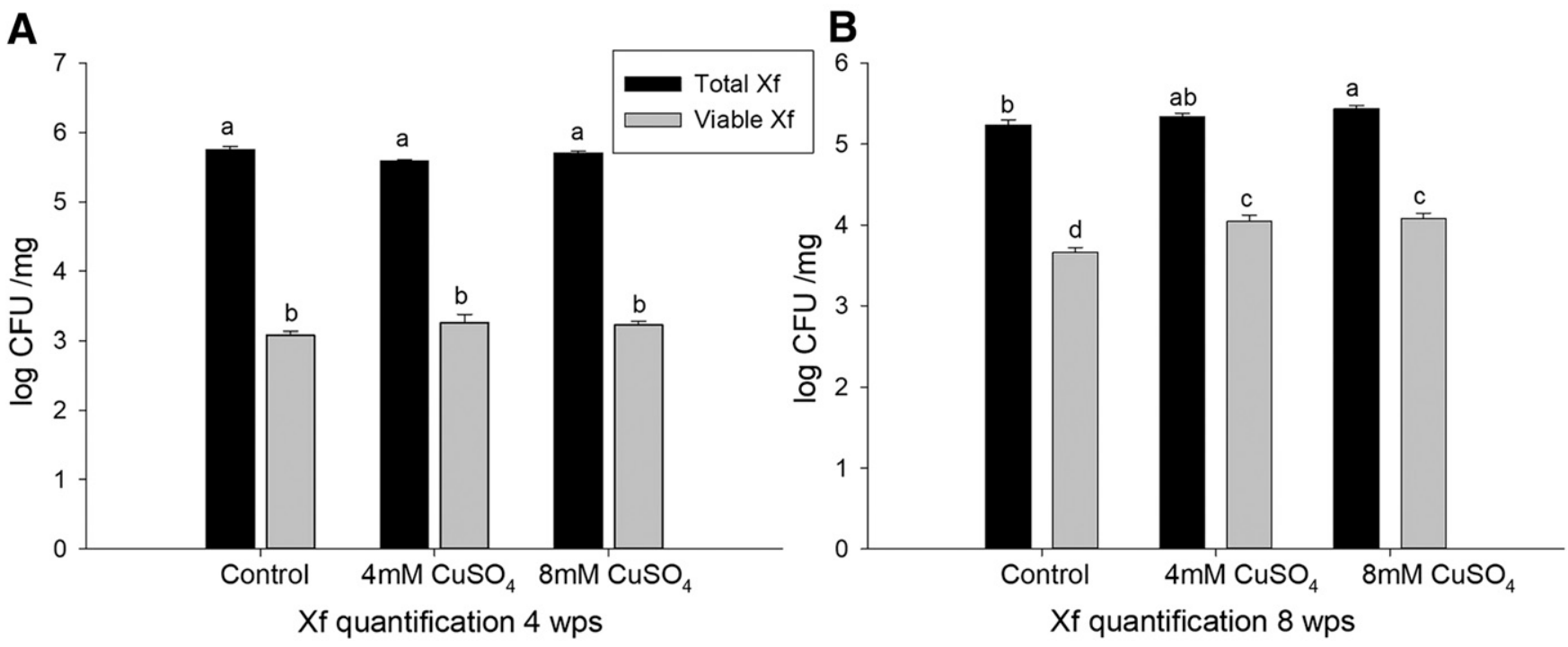

Fig. 5. Quantification Xylella fastidiosa (Xf) in tobacco plants. Bacterial populations were assessed at A, 4 weeks postsymptom appearance (wps) and B, 8 wps. The total $X$. fastidiosa population was measured by quantitative PCR (qPCR), and viable $X$. fastidiosa was measured by PMAxx-qPCR. Different letters indicate a significant difference $(P<0.05)$ between treatments according to one-way analysis of variance or the Kruskal-Wallis test. Error bars in both $A$ and $B$ correspond to the standard error of the mean. Data used in the graphs correspond to one representative experiment. Three independent experiments performed under the same conditions showed similar tendencies. 
the range that increased bacterial growth and biofilm formation in vitro (Cobine et al. 2013). A possible explanation for the tendency to show more symptoms at higher $\mathrm{Cu}$ concentrations is increased biofilm formation in the xylem, but this requires further investigation. Noteworthy is the observation that viable bacterial populations were higher in petioles of $\mathrm{Cu}$-treated plants at later time points ( $8 \mathrm{wps}$ ), although it cannot be determined by our analysis whether cells were forming biofilm. In addition, infected plants accumulated more $\mathrm{Cu}$, which may have enhanced phytotoxicity. Our study treated plants with $\mathrm{Cu}$ only, as opposed to mixing $\mathrm{Cu}$ with $\mathrm{Zn}$ as in a field study concerned with suppression of olive quick decline syndrome (Scortichini et al. 2019). In that study, a $\mathrm{Cu}$ and $\mathrm{Zn}$ mixture was added to olive trees with a citric acid biocomplex (Dentamet), and plants showed increased survival and decreased $X$. fastidiosa populations (Scortichini et al. 2019). Differences in the results may be attributable to different plant species tested in these studies or to $\mathrm{Cu}$ bioavailability; however, the concentration of leaf $\mathrm{Cu}$ was similar in both studies. We observed a much lower accumulation of $\mathrm{Zn}$ in our studies compared with the study in olives (Scortichini et al. 2019), and the combination of $\mathrm{Cu}$ and $\mathrm{Zn}$ plus other components in the mixture may have contributed to the Dentamet action.

Viable bacterial cells in plants were quantified by PMAxx-qPCR. To check the accuracy of the technique with plant samples, we used a control with heat-killed cells. In that control, "live/viable" bacteria cells were still calculated at $2.18 \mathrm{log} \mathrm{CFU} / \mathrm{mg}$ (4.46 log CFU/mg for total cells using regular qPCR), where "dead cells" represented approximately $0.5 \%$ of total cells. Similar results described by others (Sicard et al. 2019) reported that for heat-killed X. fastidiosa, approximately 0.2 to $0.5 \%$ of cells had amplified DNA after PMAxx treatment. The authors suggested that some cells may still be alive after heat treatment or that the PMAxx treatment did not reduce the qPCR signal completely (Sicard et al. 2019). Other studies found that the efficiency of the dye depends on the plant species (Randazzo et al. 2016) and is influenced by other factors such as the primers and polymerase used (Escudero-Abarca et al. 2014). Meanwhile, the incubation conditions, such as buffer, light type, and surfactants added, could have all influenced the results (Fittipaldi et al. 2012; Moreno et al. 2015; Randazzo et al. 2016). In our study, we suggest that the viable cells measured by this method could be a reference to the number of viable cells in the plant but probably do not represent an absolute population value.

In this research, tobacco plants were grown in $\mathrm{Cu}$-supplemented soil, where plant $\mathrm{Cu}$ accumulation was significantly higher than controls watered with tap water; however, we did not notice symptoms related to $\mathrm{Cu}$ toxicity in plants (when drenched at 4 and $8 \mathrm{mM}$ of $\left.\mathrm{CuSO}_{4}\right) . \mathrm{Cu}$ toxicity was observed when plants were watered with higher $\mathrm{Cu}$ concentrations (12 and $16 \mathrm{mM}$ ). Symptoms of $\mathrm{Cu}-$ induced phytotoxicity observed included chlorosis of the vegetative parts, reduced root growth, and photosynthesis alterations, as previously described (Culotta and Scott 2016). Plant Cu homeostasis helps avoid excess $\mathrm{Cu}$ and therefore prevents toxicity. $\mathrm{Cu}$ transporters play an important role in regulating $\mathrm{Cu}$ content in the cytosol. ATP-independent $\mathrm{Cu}$ transporters, yellow stripe-like transporters, and ZRTIRT-like transporters are involved in $\mathrm{Cu}$ import into the cytosol, whereas $\mathrm{P}_{1 \mathrm{~B}}$-type ATPases are related to $\mathrm{Cu}$ export outside of the cytosol (Kampfenkel et al. 1995; Pilon 2011; Puig et al. 2007). Once in the cytosol, metallothioneins and phytochelatins can bind $\mathrm{Cu}$ to decrease free $\mathrm{Cu}$ ion in plant cells (Burkhead et al. 2009). Research shows that sap leakage from the trunk and twigs is a strategy of plants to reduce accumulation of $\mathrm{Cu}$ after high dosages of this element (Hippler et al. 2018). We hypothesize that functional plant $\mathrm{Cu}$ homeostasis restricts $\mathrm{Cu}$ uptake to a tight range, and $X$. fastidiosa takes advantage of this set point to gain sufficient $\mathrm{Cu}$ from sap for its own growth, which leads to increased bacterial growth, biofilm formation, and more severe disease.

$\mathrm{Cu}$ treatments to control plant diseases have been applied in the field for more than a century, particularly the Bordeaux mixture containing $\mathrm{Cu}$-sulfate combined with $\mathrm{Ca}$-hydroxide. The long-term usage of these management strategies has led to $\mathrm{Cu}$ accumulation in field soils and we must now consider the possible consequences this might cause. $X$. fastidiosa appears to be able to grow under $\mathrm{Cu}$ treatment by soil drench, and we have shown extensively that $\mathrm{Ca}$ enhances the virulence traits of $X$. fastidiosa strains (Cruz et al. 2012; Parker et al. 2016). Cu from polluted soils could serve as a booster for endophyte pathogen growth, as we showed in this study. This is a reminder that plant disease management in the field should focus on not just the efficiency of controlling one single pathogen but also the influence on nontarget microflora.

\section{Acknowledgments}

We thank Amy N. Wright, associate dean for instruction at Auburn University College of Agriculture, for help with the Scholander pump used in this research. We also thank Rachael Gravel for help with sample preparation.

\section{Literature Cited}

Angelova, V. R., Ivanov, A. S., and Braikov, D. M. 1999. Heavy metals (Pb, Cu, $\mathrm{Zn}$ and $\mathrm{Cd}$ ) in the system soil-grapevine-grape. J. Sci. Food Agric. 79:713-721.

Ballabio, C., Panagos, P., Lugato, E., Huang, J. H., Orgiazzi, A., Jones, A. Fernandez-Ugalde, O., Borrelli, P., and Montanarella, L. 2018. Copper distribution in European topsoils: An assessment based on LUCAS soil survey. Sci. Total Environ. 636:282-298.

Behlau, F., Hong, J. C., Jones, J. B., and Graham, J. H. 2013. Evidence for acquisition of copper resistance genes from different sources in citrusassociated xanthomonads. Phytopathology 103:409-418.

Bender, C. L., and Cooksey, D. A. 1987. Molecular cloning of copper resistance genes from Pseudomonas syringae pv. tomato. J. Bacteriol. 169:470-474.

Brun, L., Maillet, J., Richarte, J., Herrmann, P., and Remy, J. 1998. Relationships between extractable copper, soil properties and copper uptake by wild plants in vineyard soils. Environ. Pollut. 102:151-161.

Brunetto, G., Bastos de Melo, G. W., Terzano, R., Del Buono, D., Astolfi, S., Tomasi, N., Pii, Y., Mimmo, T., and Cesco, S. 2016. Copper accumulation in vineyard soils: Rhizosphere processes and agronomic practices to limit its toxicity. Chemosphere 162:293-307.

Burkhead, J. L., Reynolds, K. A. G., Abdel-Ghany, S. E., Cohu, C. M., and Pilon, M. 2009. Copper homeostasis. New Phytol. 182:799-816.

Campbell, C. L., and Madden, L. V. 1990. Introduction to Plant Disease Epidemiology. John Wiley \& Sons, New York, NY.

Chatterjee, S., Almeida, R. P., and Lindow, S. 2008. Living in two worlds: The plant and insect lifestyles of Xylella fastidiosa. Annu. Rev. Phytopathol. 46: 243-271.

Cobine, P. A., Cruz, L. F., Navarrete, F., Duncan, D., Tygart, M., and De La Fuente, L. 2013. Xylella fastidiosa differentially accumulates mineral elements in biofilm and planktonic cells. PLoS One 8:e54936.

Cruz, L. F., Cobine, P. A., and De La Fuente, L. 2012. Calcium increases Xylella fastidiosa surface attachment, biofilm formation, and twitching motility. Appl Environ. Microbiol. 78:1321-1331.

Culotta, V., and Scott, R. A. 2016. Metals in Cells. John Wiley \& Sons, New York, NY.

Davis, M., Purcell, A., and Thomson, S. 1980. Isolation media for the Pierce's disease bacterium. Phytopathology 70:425-429.

Davis, M. J., French, W. J., and Schaad, N. W. 1981. Axenic culture of the bacteria associated with phony disease of peach and plum leaf scald. Curr. Microbiol. 6 309-314.

De La Fuente, L., Parker, J. K., Oliver, J. E., Granger, S., Brannen, P. M., van Santen, E., and Cobine, P. A. 2013. The bacterial pathogen Xylella fastidiosa affects the leaf ionome of plant hosts during infection. PLoS One 8:e62945.

Doyle, J. J., and Doyle, J. L. 1987. A rapid DNA isolation procedure for small quantities of fresh leaf tissue. Phytochem. Bull. 19:11-15.

Escudero-Abarca, B., Rawsthorne, H., Goulter, R., Suh, S., and Jaykus, L. 2014. Molecular methods used to estimate thermal inactivation of a prototype human norovirus: More heat resistant than previously believed? Food Microbiol. 41:91-95.

Fittipaldi, M., Nocker, A., and Codony, F. 2012. Progress in understanding preferential detection of live cells using viability dyes in combination with DNA amplification. J. Microbiol. Methods 91:276-289.

Flores-Vélez, L., Ducaroir, J., Jaunet, A., and Robert, M. 1996. Study of the distribution of copper in an acid sandy vineyard soil by three different methods. Eur. J. Soil Sci. 47:523-532.

Francis, M., Civerolo, E. L., and Bruening, G. 2008. Improved bioassay of Xylella fastidiosa using Nicotiana tabacum cultivar SR1. Plant Dis. 92:14-20.

Girelli, C. R., Del Coco, L., Scortichini, M., Petriccione, M., Zampella, L., Mastrobuoni, F., Cesari, G., Bertaccini, A., D’Amico, G., Contaldo, N., Migoni, D., and Fanizzi, F. P. 2017. Xylella fastidiosa and olive quick decline syndrome (CoDiRO) in Salento (southern Italy): A chemometric $1 \mathrm{H}$ NMR-based preliminary study on Ogliarola Salentina and Cellina di Nardò cultivars. Chem. Biol. Technol. Agric. 4.1:25.

Graham, J. H., Dewdney, M. M., and Myers, M. E. 2010. Streptomycin and copper formulations for control of citrus canker on grapefruit. Proc. Fla. State Hortic. Soc. 123:92-99. 
Hippler, F. W. R., Petena, G., Boaretto, R. M., Quaggio, J. A., Azevedo, R. A., and Mattos-Jr, D. 2018. Mechanisms of copper stress alleviation in Citrus trees after metal uptake by leaves or roots. Environ. Sci. Pollut. Res. Int. 25:13134-13146.

Hong, J., Rico, C. M., Zhao, L., Adeleye, A. S., Keller, A. A., Peralta-Videa, J. R., and Gardea-Torresdey, J. L. 2015. Toxic effects of copper-based nanoparticles or compounds to lettuce (Lactuca sativa) and alfalfa (Medicago sativa). Environ. Sci. Process. Impacts 17:177-185.

Hopkins, D., and Purcell, A. 2002. Xylella fastidiosa: Cause of Pierce's disease of grapevine and other emergent diseases. Plant Dis. 86:1056-1066.

Janse, J., and Obradovic, A. 2010. Xylella fastidiosa: Its biology, diagnosis, control and risks. J. Plant Pathol. 92(suppl 1):S35-S48.

Kampfenkel, K., Möhlmann, T., Batz, O., Van Montagu, M., Inzé, D., and Neuhaus, H. E. 1995. Molecular characterization of an Arabidopsis thaliana cDNA encoding a novel putative adenylate translocator of higher plants. FEBS Lett. 374:351-355.

Komárek, M., Cadkova, E., Chrastny, V., Bordas, F., and Bollinger, J. C. 2010. Contamination of vineyard soils with fungicides: A review of environmental and toxicological aspects. Environ. Int. 36:138-151.

Lai, H.-Y., Juang, K.-W., and Chen, B.-C. 2010. Copper concentrations in grapevines and vineyard soils in central Taiwan. Soil Sci. Plant Nutr. 56: 601-606.

Lamichhane, J. R., Osdaghi, E., Behlau, F., Köhl, J., Jones, J. B., and Aubertot, J.-N. 2018. Thirteen decades of antimicrobial copper compounds applied in agriculture. A review. Agron. Sustain. Dev. 38:28.

Mackie, K. A., Muller, T., and Kandeler, E. 2012. Remediation of copper in vineyards-a mini review. Environ. Pollut. 167:16-26.

Macomber, L., and Imlay, J. A. 2009. The iron-sulfur clusters of dehydratases are primary intracellular targets of copper toxicity. Proc. Natl. Acad. Sci. U.S.A. 106:8344-8349.

Mirlean, N., Roisenberg, A., and Chies, J. O. 2007. Metal contamination of vineyard soils in wet subtropics (southern Brazil). Environ. Pollut. 149:10-17.

Moreno, L., Aznar, R., and Sánchez, G. 2015. Application of viability PCR to discriminate the infectivity of hepatitis A virus in food samples. Int. J. Food Microbiol. 201:1-6.

Newman, K. L., Almeida, R. P. P., Purcell, A. H., and Lindow, S. E. 2003. Use of a green fluorescent strain for analysis of Xylella fastidiosa colonization of Vitis vinifera. Appl. Environ. Microbiol. 69:7319-7327.

Oliver, J. E., Cobine, P. A., and De La Fuente, L. 2015. Xylella fastidiosa isolates from both subsp. multiplex and fastidiosa cause disease on southern highbush blueberry (Vaccinium sp.) under greenhouse conditions. Phytopathology 105:855-862.

Oliver, J. E., Sefick, S. A., Parker, J. K., Arnold, T., Cobine, P. A., and De La Fuente, L. 2014. Ionome changes in Xylella fastidiosa-infected Nicotiana tabacum correlate with virulence and discriminate between subspecies of bacterial isolates. Mol. Plant-Microbe Interact. 27:1048-1058.
Parker, J. K., Chen, H., McCarty, S. E., Liu, L. Y., and De La Fuente, L. 2016. Calcium transcriptionally regulates the biofilm machinery of Xylella fastidiosa to promote continued biofilm development in batch cultures. Environ. Microbiol. 18:1620-1634.

Parker, J. K., Havird, J. C., and De La Fuente, L. 2012. Differentiation of Xylella fastidiosa strains via multilocus sequence analysis of environmentally mediated genes (MLSA-E). Appl. Environ. Microbiol. 78:1385-1396.

Pilon, M. 2011. Moving copper in plants. New Phytol. 192:305-307.

Puig, S., Andrés-Colás, N., García-Molina, A., and Penarrubia, L. 2007. Copper and iron homeostasis in Arabidopsis: Responses to metal deficiencies, interactions and biotechnological applications. Plant Cell Environ. 30:271-290.

Purcell, A. H., and Hopkins, D. L. 1996. Fastidious xylem-limited bacterial plant pathogens. Annu. Rev. Phytopathol. 34:131-151.

Randazzo, W., Lopez-Galvez, F., Allende, A., Aznar, R., and Sanchez, G. 2016. Evaluation of viability PCR performance for assessing norovirus infectivity in fresh-cut vegetables and irrigation water. Int. J. Food Microbiol. 229:1-6.

Rusjan, D. 2012. Copper in horticulture. Pages 257-278 in Fungicides for Plant and Animal Diseases. D. Dhanasekaran, N. Thajuddin, and A. Panneerselvam eds. InTech, London, UK.

Ruyters, S., Salaets, P., Oorts, K., and Smolders, E. 2013. Copper toxicity in soils under established vineyards in Europe: A survey. Sci. Total Environ. 443 470-477.

Saponari, M., Giampetruzzi, A., Loconsole, G., Boscia, D., and Saldarelli, P. 2019 Xylella fastidiosa in olive in Apulia: Where we stand. Phytopathology 109: 175-186.

Scortichini, M., Migoni, D., Angile, F., Del Coco, L., Girelli, C. R., Zampella, L., Mastrobuoni, F., and Fanizzi, F. P. 2019. Xylella fastidiosa subsp. pauca on olive in Salento (Southern Italy): Infected trees have low in planta micronutrient content. Phytopathol. Mediterr. 58:39-48.

Sharma, S. S., and Dietz, K.-J. 2009. The relationship between metal toxicity and cellular redox imbalance. Trends Plant Sci. 14:43-50.

Sicard, A., Merfa, M. V., Voeltz, M., Zeilinger, A. R., De La Fuente, L., and Almeida, R. P. 2019. Discriminating between viable and membrane-damaged cells of the plant pathogen Xylella fastidiosa. PLoS One 14:e0221119.

Solioz, M., Abicht, H. K., Mermod, M., and Mancini, S. 2010. Response of Grampositive bacteria to copper stress. J. Biol. Inorg. Chem. 15:3-14.

Sun, X., Ma, T., Yu, J., Huang, W., Fang, Y., and Zhan, J. 2018. Investigation of the copper contents in vineyard soil, grape must and wine and the relationship among them in the Huaizhuo Basin Region, China: A preliminary study. Food Chem. 241:40-50.

Wightwick, A. M., Mollah, M. R., Partington, D. L., and Allinson, G. 2008. Copper fungicide residues in Australian vineyard soils. J. Agric. Food Chem. $56: 2457-2464$ 